\title{
Produktif Saat Pandemi melalui Edukasi Hidroponik dan Aquaponik untuk Masyarakat Perkotaan (Studi Kasus: Kota Bekasi, Jawa Barat)
}

\section{(Productive During a Pandemic through Hydroponic and Aquaponic Education for Urban Communities (Case Study: Bekasi City, West Java)}

\author{
Divary Raihan Pratama ${ }^{1}$, Nadia Fauzana ${ }^{2}$, Ryan Arif Basardi ${ }^{3}$, Laily Dwi Arsyianti ${ }^{4^{*}}$ \\ ${ }^{1}$ Departemen Ilmu dan Teknologi Kelautan, Fakultas Perikanan dan Ilmu Kelautan, \\ Institut Pertanian Bogor, Kampus IPB Darmaga, Bogor 16680. \\ ${ }^{2}$ Departemen Proteksi Tanaman, Fakultas Pertanian, Institut Pertanian Bogor, Kampus IPB Darmaga, Bogor 16680 \\ ${ }^{3}$ Departemen Agribisnis, Fakultas Ekonomi dan Manajemen, Institut Pertanian Bogor, \\ Kampus IPB Darmaga, Bogor 16680. \\ ${ }^{4}$ Departemen Ilmu Ekonomi Syariah, Fakultas Ekonomi dan Manajemen, Institut Pertanian Bogor, \\ Kampus IPB Darmaga, Bogor 16680. \\ *Penulis Korespondensi: arsyianti@apps.ipb.ac.id \\ Diterima September 2020/Disetujui April 2021
}

\begin{abstract}
ABSTRAK
Indonesia merupakan salah satu negara di dunia yang terdampak pandemi Covid-19. Pencegahan dan penanggulangan telah dilakukan oleh berbagai pihak terhadap pandemi yang terjadi sejak bulan Maret 2020 . Sektor pertanian dapat menjadi penopang penguatan ekonomi yang sedang melemah sekaligus mencegah terjadinya krisis pangan. Diversifikasi pangan dan tidak mengandalkan sepenuhnya pada jumlah pangan yang tersedia di pasar harus menjadi perhatian khusus di masa ini. Tujuan kegiatan ini adalah untuk memanfaatkan sumber daya lahan terbatas pada wilayah perkotaan agar lebih produktif di masa pandemi. Teknik hidroponik dan aquaponik dalam sistem pertanian memberikan peluang kepada masyarakat yang tinggal di pedesaan maupun di perkotaan untuk memanfaatkan lahan pekarangan yang tidak terlalu luas. Teknologi ini dipercaya dapat memenuhi kebutuhan pangan keluarga serta mampu memberikan alternatif sumber penghasilan yang memadai. Edukasi kepada masyarakat terkait teknik ini sangat dibutuhkan, mengingat pada masa ini masyarakat sangat membutuhkan solusi alternatif bagi pemenuhan kebutuhan pangan serta penghasilan tambahan atau bahkan menjadi sumber penghasilan bagi para keluarga yang terkena dampak Covid-19.
\end{abstract}

Kata kunci: aquaponik, hidroponik, ketahanan pangan

\begin{abstract}
Indonesia is one of countries affected by the pandemic of Covid-19. All aspects of prevention and countermeasures have been carried out by various parties around the world regarding the pandemic that has occurred from March 2020 to the present. The agricultural sector is of concern because it has an important role and is closely related to national food security, as well as the supporting sector to strengthen Indonesia economy, particularly in such condition. Agriculture also can offer a solution to avoid food crises. One of the activities is to diversify food and not rely entirely on the amount of food in the market. This activity attempts to utilized limited area available in the city, thus it becomes more productive especially during pandemic. The hydroponic and aquaponic system of agricultural cultivation technology provides an alternative to be used as an adequate source of income and can meet family food needs. This technique can be carried out by people who live both in rural and urban areas which is not required a wide space. This activity can strengthen family food security as well as become additional income or even the main income of the family.
\end{abstract}

Keywords: aquaponic, food security, hidroponic

\section{PENDAHULUAN}

Covid-19 merupakan penyakit menular yang telah menyebar dan sekurang-kurangnya telah menginfeksi 1 juta orang dan sebanyak 90\% negara di dunia telah menjadi korban. Virus corona merupakan virus yang menyerang saluran pernapasan manusia (Ramadayanti 2020). Pada 16 Februari 2020, dilaporkan telah terjadi 51.857 kasus konfirmasi di 25 negara dengan 1.669 kematian. Berdasarkan data per 18 Mei dari Dashboard Darurat Kesehatan WHO, 
telah dilaporkan total 4.628.903 kasus yang dikonfirmasi, 312.009 kasus kematian yang tersebar di 216 negara. di seluruh dunia sejak awal epidemi (WHO 2020).

Pencegahan dan penanggulangan telah dilakukan oleh berbagai pihak di seluruh dunia terhadap pandemi yang terjadi sejak bulan Maret 2020 termasuk Indonesia. Pada masa pandemi dengan keterbatasan aktivitas yang diperkenankan oleh pemerintah, ketahanan pangan menjadi sesuatu yang harus diupayakan untuk menghindar dari krisis pangan yang dihadapi Indonesia, terutama akses terhadap pangan (Rachman 2016). Salah satu kegiatan yang dapat dilakukan untuk mencegah terjadinya krisis pangan adalah melakukan diversifikasi makanan, mendekatkan akses pangan, dan tidak mengandalkan sepenuhnya pada jumlah pangan yang ada di pasaran. Cara yang dapat dilakukan agar tidak mengandalkan sepenuhnya pada jumlah pangan yang ada di pasaran adalah melakukan kegiatan optimalisasi pekarangan.

Hidroponik merupakan salah satu metode hortikultura menumbuhkan tanaman melalui media tanam tertentu, namun lebih banyak berupa non-tanah yang disisipkan nutrisi-nutrisi khusus yang sesuai (Gericke 1937). Uddin \& Dhar (2018) menyatakan bahwa sistem hidroponik mampu menghasilkan produksi tanaman yang relatif tinggi dan dengan frekuensi lebih sering, serta lebih kaya gizi.

Sistem hidroponik terbukti mampu memberikan hasil produksi yang lebih baik dibandingkan budi daya di rumah kaca maupun di lingkungan terbuka sebagaimana penelitian yang telah diterapkan di wilayah Eropa (Romeo et al. 2018). Sistem hidroponik vertikal di perkotaan sangat cocok dibuat sebagai suatu sistem yang produktif, tidak hanya untuk pemenuhan kebutuhan rumah tangga, melainkan sebagai sumber penghasilan (Poznickova 2019).

Mahela dan Sutanto (2006) menyebutkan bahwa ketahanan pangan merupakan suatu sistem yang terintegrasi yang terdiri atas berbagai subsistem. Subsistem utamanya adalah ketersediaan pangan, distribusi pangan dan konsumsi pangan. Terwujudnya ketahanan pangan merupakan sinergi dari interaksi ketiga subsistem tersebut. Dalam undang-undang No 7 Tahun 1996 tentang pangan, pengertian ketahanan pangan adalah kondisi terpenuhinya pangan bagi rumah tangga yang tercermin dari ketersediaan yang cukup, baik jumlah maupun mutunya, aman, merata, dan terjangkau. Kalau kita bisa memanfaatkannya dengan baik, kita akan dapat mempertahankan kedaulatan pangan kita. Melalui sistem pertanian, kekayaan dan keanekaragaman hayati harus dapat dikelola dan dikembangkan sehingga mampu menjamin ketersediaan pangan.

Teknologi budi daya pertanian sistem hidroponik memberikan alternatif bagi para petani yang memiliki lahan sempit atau yang hanya memiliki pekarangan rumah untuk dapat melaksanakan kegiatan usaha yang dapat dijadikan sebagai sumber penghasilan yang memadai (Tim karya tani mandiri 2010). Hidroponik adalah cara bercocok tanam tanpa tanah tetapi menggunakan air dengan pemberian unsur hara terkendali berisi unsur-unsur esensial yang dibutuhkan untuk pertumbuhan tanaman (Siswandi \& Yuwono dalam Purwasih et al. 2019). Hidroponik sangat mudah, terkendali, dan bisa dilakukan di media tanpa tanah, bahkan dapat dibudidayakan di dalam rumah (Rakhman et al. 2015).

Aquaponik merupakan sebuah sistem yang memadukan pengembangbiakan hewan yang hidup di perairan dengan tanaman pada sistem hidroponik dalam perpaduan lingkungan yang saling mendukung dan menguntungkan (mutualisme). Hochman et al. (2018) mengungkapkan pemanfaatan limbah hasil sistem kombinasi aquaponik dan hidroponik agar tidak menjadi eksternalitas yang negatif, tidak terbuang, melainkan menjadi positif dan lebih dimanfaatkan.

Teknik "Budikdamber" (budi daya ikan dalam ember) atau aquaponik pertama kali ditemukan oleh dosen dari fakultas Budidaya Perikanan dari Politeknik Negeri Lampung, Juli Nursandi melalui teknik ini dapat dilakukan oleh masyarakat yang tinggal di pedesaan maupun di perkotaan dengan memanfaatkan lahan pekarangan yang tidak terlalu luas (Susetya \& Harahap 2018). Secara teknis, sistem akuaponik mampu meningkatkan kapasitas produksi pembudidaya ikan. Hal ini dikarenakan sistem akuaponik merupakan gabungan teknologi akuakultur dengan teknologi hidroponik dalam satu sistem untuk mengoptimalkan penggunaan air dan tempat sebagai media pemeliharaan (Nugroho et al. 2012). Keunggulan sistem akuaponik ini adalah dapat memenuhi ketahanan pangan rumah tangga perkotaan dengan satu tempat bisa membudidayakan sayuran dan juga ikan, sehingga pemenuhan gizi keluarga saat pandemi covid-19 dapat terpenuhi dengan baik (Dauhan et al. 2014). Melalui teknik budi daya semacam ini juga mampu memperkuat ketahanan pangan keluarga, hal ini disebabkan masyarakat tidak hanya melakukan budi daya ikan lele namun juga 
bercocok tanam secara aquaponik (Perwitasari \& Amani 2019).

Program edukasi hidroponik dan aquaponik adalah merupakan salah satu program peserta KKN-T IPB 2020 di Desa Pengasinan, Kecamatan Rawalumbu, Kota Bekasi. Program ini dilaksanakan untuk meningkatkan wawasan kepada masyarakat terkait hidroponik dan aquaponik guna meningkatkan pendapatan ekonomi dan meningkatkan ketahanan pangan rumah tangga. Tujuan kegiatan ini adalah untuk memanfaatkan sumber daya lahan terbatas pada wilayah perkotaan agar lebih produktif di masa pandemi

\section{METODE PELAKSANAAN KEGIATAN}

\section{Lokasi dan Partisipan Kegiatan}

Kegiatan ini dilakukan di Desa Pengasinan RW 08, Kecamatan Rawalumbu, Kota Bekasi, Jawa Barat pada bulan Juli-Agustus 2020. Partisipan merupakan seluruh warga RW 08 di Desa Pengasinan yang terdiri dari RT 01-10, karang taruna, ketua ibu PKK, dan warga RW 08.

\section{Bahan dan Alat}

Alat dan bahan yang digunakan pada kegiatan ini adalah: bahan power point yang berisi materi mengenai langkah-langkah menanam secara hidroponik dan budi daya lele serta kangkung dalam ember, laptop, smartphone yang suda terinstall Whatsapp, bibit sayuran, dan bibit lele.

\section{Metode Pelaksanaan Kegiatan}

Program ini dilaksanakan untuk membantu dan meningkatkan ketahanan pangan rumah tangga warga RW 08. Program edukasi hidroponik dan aquaponik ini melibatkan beberapa warga RW 08, ketua RW, Ketua RT 09, karang taruna, dan ketua ibu PKK. Program ini dilakukan pada setiap hari Sabtu/Minggu dalam waktu tiga minggu. Adapun kegiatan edukasi yang diberikan adalah edukasi hidroponik, edukasi aquaponik, praktik hidroponik bersama RT 09, dan edukasi online.

\section{- Edukasi hidroponik}

Kegiatan penyuluhan pertama merupakan kegiatan edukasi pertama yang disampaikan oleh kelompok tim pelaksana kepada warga RW 08. Edukasi tersebut berisi tentang kegiatan produktif, yaitu pembuatan hidroponik sederhana dengan menggunakan botol bekas. Tim pelaksana memberikan pengetahuan bagaimana cara menanam sayuran menggunakan lahan terbatas dengan menggunakan metode hidroponik. Pemaparan diberikan melalui presentasi secara langsung menggunakan power point. Kemudian juga dilakukan demo pembuatan hidroponik sederhana yang dilakukan oleh mahasiswa/i KKNT IPB. Diakhiri dengan sesi tanya jawab dari warga yang hadir. Warga yang hadir diberikan handsanitizer, masker, bibit sayuran, dan sumbu hidroponik secara gratis oleh tim KKN.

\section{- Edukasi aquaponik}

Kegiatan penyuluhan kedua merupakan kegiatan edukasi kedua yang disampaikan oleh tim KKN kepada warga RT 09. Edukasi tersebut berisi tentang kegiatan produktif, yaitu pembuatan hidroponik sederhana menggunakan botol bekas dan ditambahkan dengan materi aquaponik berupa budi daya lele dan kangkung dalam ember. Pemaparan materi disampaikan dengan presentasi dan dilakukan juga demo pembuatan hidroponik dan aquaponik kepada warga RT 09 dan karang taruna. Pemaparan ini dilengkapi dengan poster yang dibagikan ke warga yang hadir, sehingga warga mengetahui langkahlangkah pembuatannya.

\section{- Praktik hidroponik bersama RT 09}

Kegiatan ini merupakan praktik di mana penyampaian metodenya sudah diberikan pada penyuluhan pertama dan kedua. Kegiatan ini dihadiri oleh Ketua RT 09 dan warga RT 09. Kegiatan ini merupakan implementasi dari edukasi yang sudah diberikan, yakni berupa penanaman hidroponik kangkung. Langkah-langkah pembuatan hidroponik dibuat secara bersama. Praktik ini diarahkan oleh mahasiswa/i KKN-T IPB dan diikuti oleh warga sesuai dengan metode.

\section{- Edukasi online}

Kegiatan ini merupakan pemberian edukasi secara daring yang diberikan kepada seluruh warga RW 08 selain edukasi secara langsung. Edukasi ini bertujuan agar materi sampai ke seluruh warga yang tidak hadir dalam edukasi secara langsung. Materi edukasi online ini sama dengan materi yang disampaikan secara langsung, yaitu berupa pemberian video mengenai hidroponik dan aquaponik. Video yang diberikan disebar kepada seluruh warga RW 08 melalui Whatsapp. Para warga dapat langsung memberi pertanyaan melalui Whatsapp jika ada yang tidak memahami materi yang disampaikan. 


\section{Metode Pengumpulan Data}

Metode pengumpulan data yang digunakan dalam penelitian ini adalah dokumentasi, observasi, dan survei kuesioner. Observasi dilakukan dengan mengamati secara langsung atau tidak langsung objek yang diteliti untuk memperoleh data yang harus dikumpulkan dalam penelitian dan berpartisipasi langsung di lapangan yang melibatkan seluruh indera. Dokumen adalah catatan peristiwa masa lalu. Dokumen bisa dalam bentuk teks, gambar atau karya peringatan. Kuisioner merupakan salah satu teknologi pengumpulan data yang dilengkapi dengan memberikan rangkaian pertanyaan atau pernyataan tertulis kepada narasumber untuk dijawab. Jenis kuesioner yang digunakan adalah kuesioner tertutup. 12 dari 27 narasumber merupakan warga yang hadir saat penyuluhan hidroponik, narasumber lainnya mendapatkan edukasi secara online melalui grup Whatsapp.

\section{Metode Pengolahan Data}

Metode pengolahan yang digunakan dalam penelitian ini, yakni reduksi data, penyajian data, dan kesimpulan (verifikasi). Tujuan reduksi data adalah untuk mempermudah data yang diperoleh pada proses pengumpulan data lapangan. Penyajian data dilakukan dengan menyediakan sekumpulan informasi terstruktur untuk menarik kesimpulan. Pasalnya, data yang diperoleh dalam proses penelitian kualitatif biasanya bersifat naratif, sehingga perlu disederhanakan tanpa mengurangi isinya. Data disajikan secara deskriptif dari kuesioner yang memenuhi. Selanjutnya dilakukan kesimpulan atau verifikasi. Pada bagian ini, peneliti mengungkapkan kesimpulan berdasarkan data yang diperoleh. Kegiatan ini bertujuan untuk mencari makna dari data yang dikumpulkan dengan mencari hubungan, persamaan atau perbedaan.

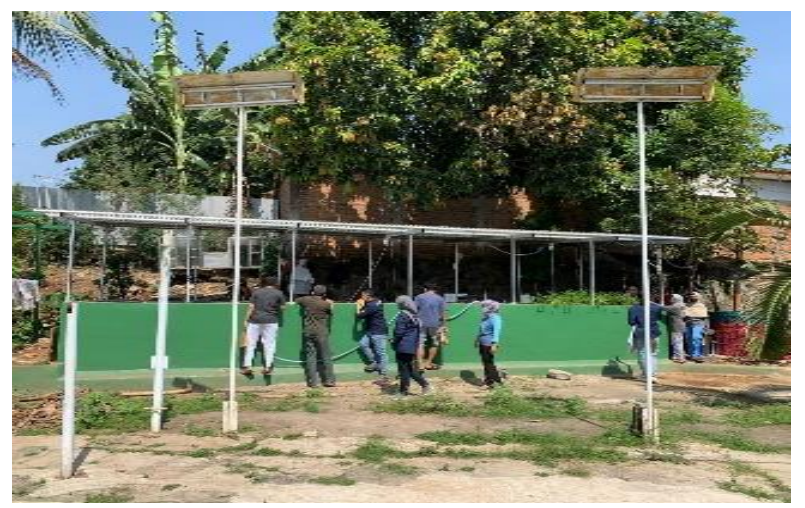

a

\section{Analisis Data}

Analisis data yang digunakan dalam penelitian ini adalah analisis kualitatif. Analisis ini dilakukan melalui pencatatan secara elektronik yang menghasilkan catatan langsung dan mengkodekannya sehingga sumber data tetap dapat dilacak atau ditelusuri. Peneliti masuk ke lapangan, mempelajari, menganalisis, menjelaskan, dan menarik kesimpulan dari fenomena di lapangan. Analisis data kualitatif bertujuan untuk mengungkap makna data penelitian dengan cara mengumpulkan data menurut kategori tertentu.

\section{HASIL DAN PEMBAHASAN}

\section{Edukasi Hidroponik}

Kegiatan edukasi hidropnik bertempat di kantor sekretariat RW 08 Jl. Pariwisata, RT 03 RW 08 . Warga yang hadir sebanyak 12 orang dengan mengikuti protokol kesehatan. Para warga sangat antusias dalam kegiatan edukasi yang diberikan dan mendengarkan pemaparan yang disampaikan oleh tim KKN-T IPB (Gambar 1). Warga diberikan pemahaman mengenai teknis atau langkah-langkah dalam pembuatan hidroponik menggunakan botol bekas dan memahami maksud dan tujuan dari pembuatan hidroponik ini, yaitu memenuhi kebutuhan pangan rumah tangga. Dampak dari program ini adalah banyak warga RW 08 yang sudah mulai untuk mencoba menanam secara hidroponik di rumahnya masing-masing. Kendala teknis masih dihadapi di lapangan, meskipun demikian, keterbatasan ini diatasi melalui pembuatan tayangan video yang disosialisasikan secara online sehingga diperoleh tanggapan 27 responden.

Mayoritas responden menyatakan telah menonton video edukasi hidroponik yang di-

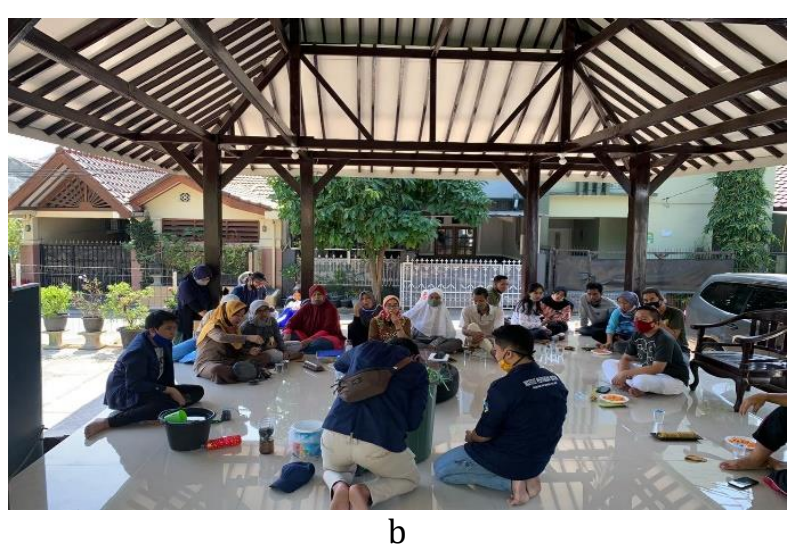

Gambar 1 a dan b Edukasi Hidroponik. 
sosialisasikan. Sebagian besar $(81,5 \%)$ dari yang telah menonton menyatakan sudah mencoba mempraktikkan hidroponik (Gambar 2). Warga melakukan aktifitas ini secara bersama di lahan umum sehingga hasil hidroponik dapat dipantau.

Responden juga menyatakan bahwa jenis tanaman yang ditanam paling banyak adalah sayuran, dilengkapi dengan tanaman hias dan pohon berjenis semak (Gambar 3). Pohon berjenis buah-buahan masih sedikit ditanam. Responden menyatakan sayuran lebih mudah untuk ditanam. Jenis sayuran yang banyak ditanam adalah kangkung, mengingat dalam kegiatan ini, bibit kangkung diberikan kepada para peserta. Selebihnya berupa bayam.

\section{Edukasi Aquaponik}

Kegiatan edukasi mengenai budi daya lele dan kangkung dalam ember yang diberikan kepada warga RT 09 mendapatkan kesan yang baik. Warga sangat antusias dalam mendengarkan pemaparan yang disampaikan oleh tim KKN-T IPB. Adapaun materi yang disampaikan, yakni teknis pembuatan aquaponik, perkenalan alat dan bahan, pakan ikan, perkenalan bibit sayuran, teknis pemberian pakan lele, dan pemeliharaan

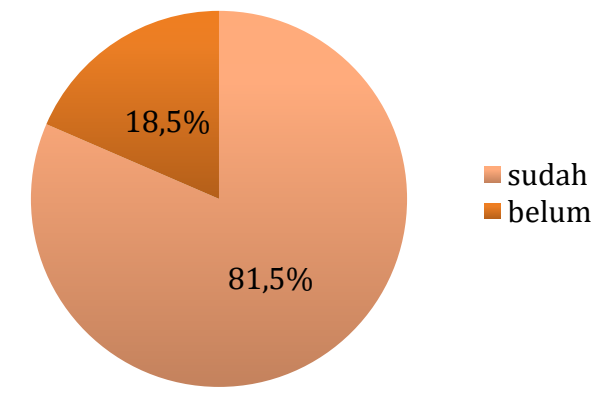

Apakah anda sudah menonton vidio cara pembuatan hidroponik?

a aquaponik. Warga yang hadir melebihi 10 orang dengan mematuhi protokol kesehatan (Gambar 4). Dampak dari kegiatan ini adalah banyak warga mengetahui dan memahami teknik pembuatan aquaponik sederhana serta dapat menjadi sarana alternatif pemenuhan kebutuhan pangan terutama karena terdapat pendampingan lanjutan dan forum diskusi. Kendala teknis masih dihadapi seperti keterlambatan pelaksanaan acara karena menunggu peserta. Namun, hal ini dapat diatasi melalui forum diskusi dan sosialisasi grup Whatsapp.

Hasil edukasi aquaponik menunjukkan 92,3\% peserta telah menerapkan sistem aquaponik sebagai aktifitas produktif di masa pandemik (Gambar 5). Keberlanjutan kegiatan ini secara optimis dijawab oleh responden akan berlangsung selama 1-2 bulan selama kegiatan edukasi pada KKNT dan sesudah KKNT berlangsung.

\section{Praktik Hidroponik Bersama RT 09}

Kegiatan ini merupakan implementasi dari edukasi yang sudah diberikan, yakni edukasi pertama (hidroponik) dan edukasi kedua (aquaponik). Tim KKN-T IPB bersama dengan warga RT 09 menanam hidroponik menggunakan

Gambar 2 a dan b Tanggapan terhadap video edukasi hidroponik.

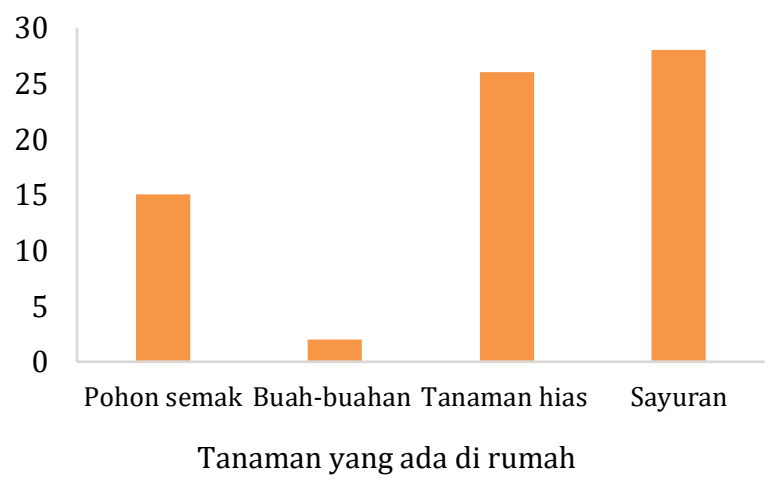

a

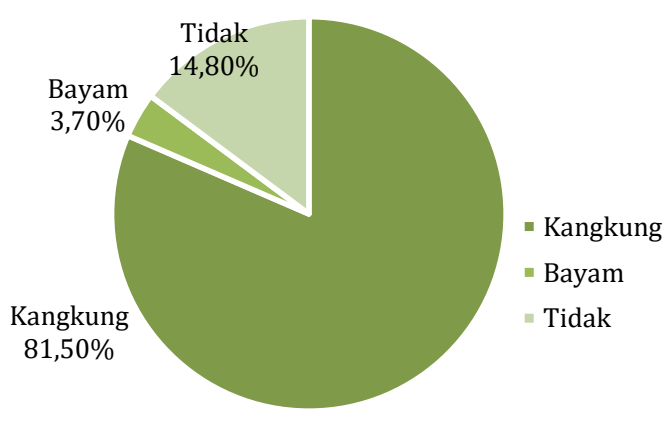

Tanaman apa yang anda tanam

b

Gambar 3 a dan b Jenis tanaman yang ditanam dengan hidroponik. 


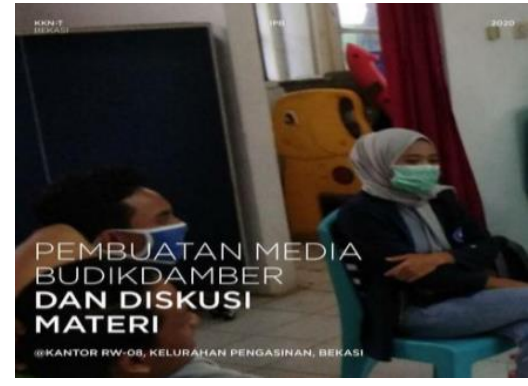

a

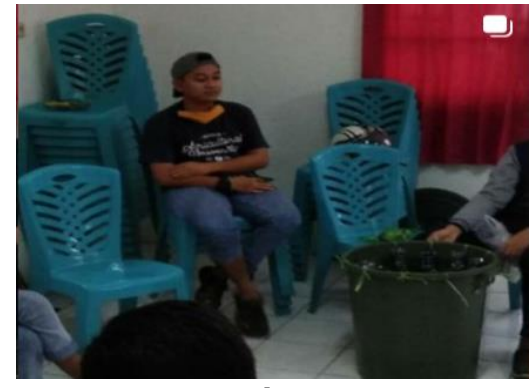

b

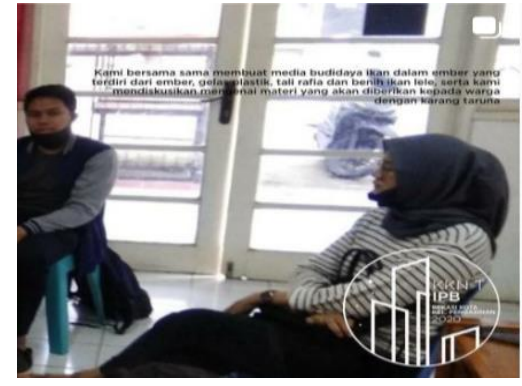

C

Gambar 4 a, b, dan c Forum diskusi aquaponik.

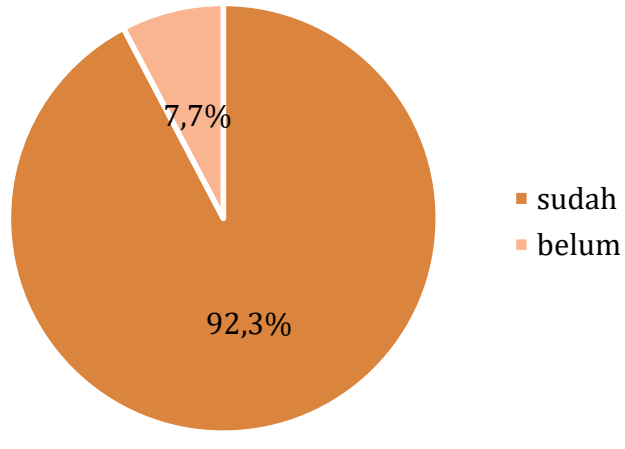

a

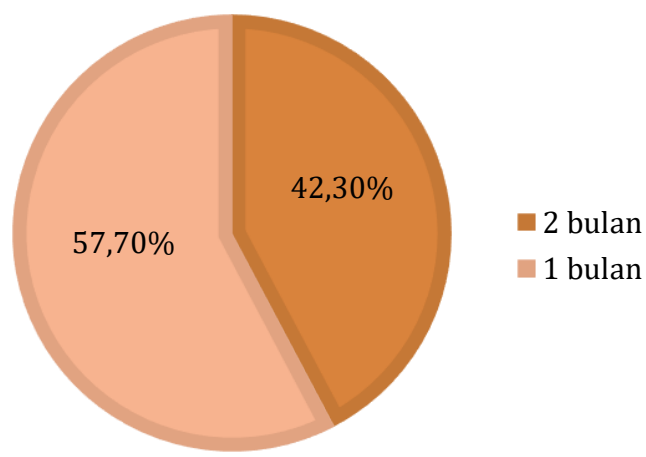

$\mathrm{b}$

Gambar 5 a dan b Tanggapan responden edukasi aquaponik.

botol bekas. Alat dan bahan disiapkan oleh kelompok KKN. Langkah-langkah pembuatan hidroponik dibuat secara bersama. Tim KKN berhasil membuat lebih dari 30 botol hidroponik yang kemudian dipajang di taman dekat pendopo RT 09. Warga yang hadir lebih dari 10 orang dengan mematuhi protokol kesehatan. Warga juga memahami apa yang disampaikan dari edukasi sebelumnya dan sangat antusias dalam kegiatan praktik hidroponik bersama ini. Dampak dari program ini adalah membuat pekarangan RT 09 menjadi lebih hijau dan indah serta dapat menjadi alternatif pemenuhan kebutuhan pangan oleh warga sekitar. Kendala yang dihadapi, yaitu terdapat warga yang terlambat mengikuti kegiatan, sehingga susunan acara menjadi terlambat pula.

\section{Edukasi Online}

Kegiatan ini merupakan pemberian pemahaman terkait hidroponik dan aquaponik secara daring melalui video kepada seluruh warga RW 08. Video diberikan melalui grup Whatsapp dan video tersebut dapat diakses oleh seluruh warga dimanapun dan kapanpun. Output dari edukasi online berupa E-book mengenai hidroponik dan aquaponik yang juga diberikan secara daring kepada seluruh warga RW 08. Terdapat kuisioner yang diberikan disetiap edukasi yang diberikan.
Kuisioner mengenai edukasi pertama (hidroponik) telah diisi oleh 27 responden dan kuisioner kedua (aquaponik) telah diisi oleh 26 responden. Hal ini menandakan warga sangat antusias mendapatkan pemahaman mengenai hidroponik dan aquaponik. Dampak dari program ini warga RW 08 dapat mengetahui dan memahami mengenai ilmu hidroponik dan aquaponik serta dapat mengaplikasikan ilmu hidroponik dan aquaponik tersebut. Kendala yang dihadapi adalah beberapa warga tidak mengisi kuisioner karena tidak memiliki waktu dan tidak memiliki kuota untuk mengakses kuisioner tersebut.

\section{Keberlanjutan Program}

Keberlanjutan program juga menjadi perihal yang harus dipertimbangkan. Pelaksanaan program akan banyak melibatkan peserta serta tokoh masyarakat yang terkait sehingga mereka dapat melanjutkan program yang telah dijalankan secara mandiri. Program yang diberikan mengenai pengetahuan berupa hidroponik sederhana, aquaponik, dan pemasaran produk, serta pengetahuan tentang Covid-19. Pengetahuan yang diberikan tersebut akan memberikan potensi kepada warga RW 08 untuk mengaplikasikan secara mandiri. Program-program yang diberikan juga dapat menjadi program yang terus 
dapat berlanjut melihat dari antusiasme warga RW 08. Tim KKNT IPB juga memberikan booklet yang berisi Panduan Pintar (Papi) mengenai perilaku hidup bersih, new normal lingkungan masyarakat, kegiatan produktif selama pandemi (hidroponik dan aquaponik), hingga pemasaran produk sayuran. Booklet ini diharapkan dapat menjadi pedoman bagi warga RW 08 untuk tetap bekerja dengan produktif selama masa pandemi.

\section{SIMPULAN}

Program edukasi yang diberikan kepada warga juga mendapatkan respons baik serta dapat dipahami oleh warga sehingga mengindikasikan warga RW 08 sangat antusias dalam mengikuti program yang diberikan. Edukasi hidroponik dan aquaponik disambut baik dengan langsung mempraktikan hidroponik bersama RT 09, dan edukasi online. Materi edukasi dapat diakses melalui media sosial instagram dan whatsapp sehingga dapat disimak kembali sewaktu-waktu dibutuhkan. Warga RW 08, Kelurahan Pengasinan juga mendapatkan E-book mengenai hidroponik dan aquaponik sehingga diharapkan warga RW 08 dapat melanjutkan kegiatan produktif selama masa pandemi Covid19, yaitu menanam hidroponik dan melakukan budi daya lele dan kangkung dalam ember untuk dapat memenuhi kebutuhan pangan rumah tangga. Program-program yang sudah dijalankan oleh tim KKNT IPB dapat dilanjutkan dan ditingkatkan kedepannya karena berdasarkan hasil kegiatan yang didapat warga RW 08 sangat antusias dengan program-program yang diberikan oleh tim KKNT IPB.

\section{DAFTAR PUSTAKA}

Dauhan RES, Efendi E, Suparmono. 2014. Efektivitas Sistem Akuaponik dalam Mereduksi Konsentrasi Amonia pada Sistem Budidaya Ikan. Jurnal Rekayasa dan Teknologi Budidaya Perairan. III(1): 297-302.

Gericke WF. 1937. Hydroponics-crop production in liquid culture media. Science. 85 (2198): 177-178. https://doi.org/10.1126/science. 85.2198.177

Hochman G, Hochman E, Naveh N, Zilberman D. 2018. The synergy between aquaculture and hydroponics technologies: The case of lettuce and tilapia. Sustainability. 10(10): 1-19. https://doi.org/10.3390/su10103479

Mahela, Sutanto. 2006. Kajian Konsep Ketahanan Pangan.Jurnal Protein. 13(2): 194-200.

Nugroho RA, Pambudi LT, Chilmawati D, Haditomo AFC. 2012. Aplikasi Teknologi Aquaponic pada Budidaya Ikan Air Tawar untuk 100 Optimalisasi kapasitas Produksi. Jurnal Saintek Perikanan. 8(1): 46-51.

Purwasih R, Evahelda, Agustina F, Pranoto YS. 2019. Pemanfaatan Lahan Pekarangan untuk Budi Daya Sayuran Secara Hidroponik di Kecamatan Sungailiat, Kabupaten Bangka, Provinsi Kepulauan Bangka Belitung. Agrokreatif Jurnal Ilmiah Pengabdian Kepada Masyarakat. 5(3): 195-201. https://doi.org/ 10.29244/agrokreatif.5.3.195-201

Perwitasari DA, Amani T. 2019. Penerapan sistem akuaponik (budi daya ikan dalam ember) untuk pemenuhan gizi dalam mencegah stunting di Desa Gending Kabupaten Probolinggo. Abdi Panca Marga. 1(1): 20-24. https://doi.org/10.51747/abdipancamarga.v $1 \mathrm{i} 1.479$

Poznickova D. 2019. Hydroponic farming and circular economy: Implementation of circular economy into hydroponic production. [Tesis]. Swedish (SE): Swedish University of Agricultural Sciences.

Rakhman A, Lanya B, Rosadi B, Kadir MZ. 2015. Pertumbuhan Tanaman Sawi Menggunakan Sistem Hidroponik Dan Akuaponik. Jurnal Teknik Pertanian Lampung. 4(4): 245-254.

Rachman HPS. 2016. Aksesibilitas pangan: faktor kunci pencapaian ketahanan pangan di Indonesia. Jurnal Pangan. 19(2): 147-156.

Ramadayanti E. 2020. Covid-19 dalam Perspektif One Health Approach dan Law Enforcement. [Internet]. [Diakses pada: 2 September 2020]. Tersedia pada: http://fh.unpad.ac.id/covid19-dalam-perspektif-one- healthapproachdan-law- enforcement/\#_ftn4.

Romeo D, Vea EB, Thomsen M. 2018. Environmental impacts of urban hydroponics in Europe: a case study in Lyon. Procedia CIRP. 69: 540-545. https://doi.org/10.1016/ j.procir.2017.11.048

Siswandi, Yuwono T. 2015. Pengaruh media tanam terhadap pertumbuhan dan hasil selada (latuca sativa L) Hidroponik. Jurnal Agronomika. 09(03): 257-264 
Susetya IE, Harahap ZA. 2018. Aplikasi budikdamber (budi daya ikan dalam ember) untuk keterbatasan lahan budi daya di Kota Medan. Abdimas Talenta. 3(2):416-420.

Tim karya tani mandiri. 2010. Pedoman Budidaya Secara Hidroponik. Bandung (ID): Nuansa Aulia.

Uddin MT, Dhar AR. 2018. Socioeconomic analysis of hydroponic fodder production in selected areas of Bangladesh: Prospects and challenges. SAARC Journal of Agriculture. 16(1): 233-247. https://doi.org/10.3329/ sja.v16i1.37438

[WHO] World Health Organization. 2020. WHO Coronavirus Disease (Covid19) Dashboard. [Internet]. [Diakses pada:]. Tersedia pada: https://covid19.who.int/. 